Vol. 7(1998): 267-282.

\title{
Contribution of modern biotechnology of lactic acid bacteria to development of health-promoting foods
}

Airi Palva

Agricultural Research Centre of Finland, Food Research, FIN-31600 Jokioinen, Finland. Current address: Faculty of Veterinary Medicine, Hämeentie 57, FIN-00014 University of Helsinki, Finland, e-mail: airi.palva@ helsinki.fi

Lactic acid bacteria (LAB) are extensively used in the manufacture of a wide variety of fermented dairy, meat, vegetable, bakery and wine products in the food and wine industry as well as in making silage for animal feed. Some LAB strains also have an increasingly important role as health-promoting probiotics. Molecular genetic research of LAB, focused mainly on the basic characterisation of traits essential for the industrial utilisation of these bacteria, forms a solid scientific basis for stabilisation, modification and improvement of these characteristics. The emphasis of this review is on the molecular genetic work done at the research laboratory of the author. Our research team is engaged on, two main projects: molecular genetic and biochemical characterisation of the proteolytic systems of industrial thermophilic lactobacilli and surface layer protein studies to develop protein production systems for food, feed, vaccine and diagnostic purposes.

Key words: aminopeptidase N, B-glucuronidase, cheese ripening, E. coli B-lactamase, in vivo expression of slpA, luciferase, oligopeptide transport system, peptidases, protein secretion

\section{Introduction}

Lactic acid bacteria (LAB) are a diverse group of micro-organisms inhabiting various ecological niches, from plant surfaces to the gastrointestinal, genital and respiratory tracts of man and animals (De Vuyst and Vandamme 1994, Wood 1992). LAB are also widely used as starters in the manufacture of fermented foods, beverages, pickled vegetables and silage (De Vuyst and Vandamme 1994). In fermentation, several metabolic properties of LAB serve special functions with a direct or indirect impact on food processes. Fermentation allows the preservation of food and affects the development of flavour and texture, whilst, starter cultures bring about a variety of beneficial metabolic and sensory changes in food (Lindgren and Dobrogosz 1990, Olson 1990, Holzapfel et al. 1995). Some milk products fermented with probiotic LAB may also have health and additional nutritional benefits, and these are increasingly being subjected to $\mathrm{R}+\mathrm{D}$ (Jensen 1995, Wood 1992). The proposed key targets of the health-promoting effects of probiotic LAB are the prevention of intestinal infections, diar-

(ㄷ) Agricultural and Food Science in Finland

Manuscript received December 1997 


\section{AGRICULTURAL AND FOOD SCIENCE IN FINLAND}

\section{Seminar in honour of the 100th anniversary of MTT}

rhoeal diseases and upper gastrointestinal tract diseases, the prevention of cancer and the hypercholesterolemia, the improvement of lactose utilisation and the stabilisation of the gut mucosal barrier (Kailasapathy and Rybka 1997, Wood 1992, Salminen et al. 1996).

The loosely defined group of LAB includes Gram-positive rods and cocci with low $\mathrm{G}+\mathrm{C}$ content $<50 \mathrm{~mol} \%$ (Pot et al. 1994). LAB are catalase negative, non-sporulating (except Sporolactobacillus), acid- and aerotolerant anaerobic bacteria that produce lactic acid as a major or sole end-product of obligative fermentative metabolism (Pot et al. 1994, Wood and Holzapfel 1995). Taxonomically LAB have been included in the genera Lactobacillus, Lactococcus, Leuconostoc, Pediococcus, Carnobacterium, Sporolactobacillus, Streptococcus, Enterococcus, Aerococcus, Vagococcus, Tetragenococcus and Atopium (Pot et al. 1994, Wood and Holzapfel 1995); This classification is, however, not final. Many characteristics typical of genuine LAB are also shared by the genus Bifidobacterium, which consists of increasingly important health-promoting intestinal bacteria (Kailasapathy and Rybka 1997). Bifidobacterium was considered to be one of the LAB, but due to their high $\mathrm{G}+\mathrm{C}$ content (55-67 mol\%) and on the basis of $16 \mathrm{~S}$ rRNA data, it is now clear that the bifidobacteria belong to the actinomyces branch in the phylogenetic trees of Gram-positive bacteria (Schleifer and Ludwig 1995).

Owing to the great diversity of LAB, especially among one of the most widely used groups, i.e. Lactobacillus, molecular genetic studies of LAB are very demanding. However, since being of such importance in the food industry, LAB, particularly the starters used in the dairy products, have been subjected to extensive molecular genetic research for many years. The objectives of that research have been to characterise, stabilise and improve traits essential for food processes (for recent reviews, see de Vos et al. 1993, Venema et al. 1996). Much is already known about the molecular biology of starter lactococci but during the last few years, a considerable amount of information has also been gathered on the various lactobacillar species. In addition to the development of genetic tools, the main research targets have been characterisation of the key metabolic genes (e.g. lactose and citrate utilisation, proteolytic enzymes) and metabolic engineering, isolation, characterisation and modification of antimicrobials for food preservation, bacteriophages and bacteriophage resistance, and its gene expression and control (de Vos et al. 1993, Gasson and de Vos 1994, Venema et al. 1996). We are gradually accumulating a very solid and promising basis for the further development of better and safer food products, possibly even with novel characteristics. Recently, work has begun on elucidating the different health-promoting effects and validating the claimed benefits of probiotics with the aid of molecular biology (Klaenhammer 1995, Tannock 1995). Furthermore, the development of LAB as oral vaccine carriers has got off to a promising start (Wells et al. 1996). These new fields have opened fascinating perspectives on novel utilisations of certain LAB strains. Eventually such applications may be seen as evidence of the major impact modern biotechnology can have on the health and nutrition of humans and animals.

This review summarises, in the context of relevant research, some of the contributions made by our LAB research team to efforts to establish a basic knowledge base for future food and health-promoting applications. In the first part of the review I shall examine the status of our work on the molecular genetic characterisation of lactobacillar proteolytic systems. The proteolytic systems of LAB are considered to have an essential impact on cheese ripening and the formation of flavour and texture in cheese. The new information now available on cheese ripening and the exact role of proteolytic and peptidolytic enzymes in the process will aid the development of low fat cheeses with a better health-affecting status. Furthermore, it will be possible to use the characterised enzymes of the proteolytic systems in the targeted production of bioactive peptides, e.g. from milk proteins. In the second part of the review I shall look at 


\section{AGRICULTURAL AND FOOD SCIENCE IN FINLAND}

Vol. 7 (1998): 267-282.

the molecular characterisation of the surface layer protein (S-protein, SlpA) and gene (slpA) of Lactobacillus brevis and the development of a protein production system based on the expression and secretion signals of slpA. The protein production systems developed for LAB are still rather unsophisticated, and the factors affecting protein production, secretion in particular, poorly characterised compared with those established for other pro- and eukaryotic organisms. Furthermore, the utility of the S-protein itself as a carrier of vaccine and diagnostic antigens is a key target of current and forthcoming research.

\section{Molecular genetic characterisation of components of the proteolytic systems of Lactobacilli}

\section{General background}

Many LAB isolated from milk products are multiple amino acid auxotrophs (Chopin 1993). In milk, the abundances of free amino acids and short peptides are very low. To grow in milk LAB are therefore highly dependent on their proteolytic system. The biochemical and genetic characteristics of the proteolytic system in lactococci have been extensively studied to ascertain the influence of the components of the system on the degradation of milk proteins, and thus on cheese ripening (for review, see Kunji et al. 1996). Briefly, the proteolytic system in lactococci consists of: i) the cell wall-associated proteinase (PrtP), which degrades casein into oligopeptides; ii) amino acid and peptide transport systems, which supply the degraded organic nitrogen source to the cell by translocating the breakdown products of casein across the cytoplasmic membrane; and iii) many different intracellular exo- and endopeptidases, which fur- ther cleave oligopeptides into shorter peptides and amino acids (Kunji et al. 1996, Fig. 1). Molecular characterisation of lactobacillar proteolytic systems, mainly of Lactobacillus delbrueckii ssp. lactis, Lactobacillus helveticus and Lactobacillus paracasei, even though it got under way several years after that of lactococci, has made rapid progress. We now have large knowledge base on these bacteria too, and it has become clear that a close overall similarity exits between the lactobacillar proteolytic systems and the lactococci (Kunji et al. 1996). Due to their high peptidolytic activity, lactobacilli, $L$. helveticus in particular, have been used in various forms to reduce bitterness, improve flavour development and accelerate the ripening of various types of cheese in processes conventionally based on the use of other starter strains (Ardö and Larsson 1989, Bartels et al. 1987a, b, El Soda 1993). Thus, genetic characterisation of the components of the lactobacillar proteolytic systems will enable us to develop more precise modifications of starter bacteria for improvements to lowfat cheeses and many other processes in the food industry.

To date, the cell wall-bound proteinase has been characterised from several Lactococcus lactis subsp. cremoris strains, two Lactobacillus casei, one Lactobacillus delbrueckii subsp bulgaricus and three L. helveticus strains, and the substrate specificities of lactococcal Prts have been described in detail (Kunji et al. 1996). Amino acid and peptide transport systems have been studied mainly in lactococci, for which $10 \mathrm{ami}$ no acid transport systems have been found but not yet cloned. The lactococcal di/tripeptide transporters and the oligopeptide transport systems have been extensively analysed and even genetically modified (Kunji et al. 1996). The most extensive molecular characterisation work has, however, been done on peptidases. Thus far, dozens of peptidases have been analysed, from Lactococcus lactis subsp. cremoris strains, $L$. delbrueckii subsp. lactis, L. helveticus and other LAB, including at least 12 peptidases with distinct substrate specificities (see Kunji et al. 1996). 


\section{AGRICULTURAL AND FOOD SCIENCE IN FINLAND}

Seminar in honour of the 100th anniversary of MTT

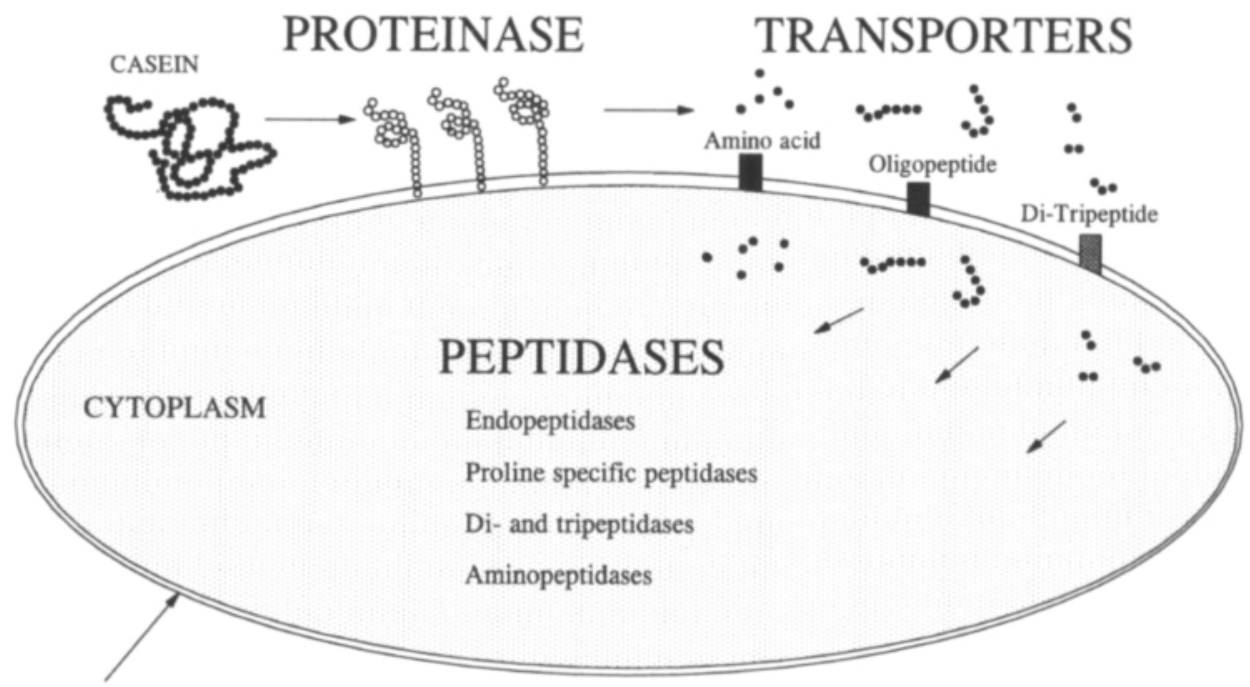

CELL WALL

Fig. 1. Schematic presentation of the proteolytic system in lactic acid bacteria. (Drawn by Kirsi Savijoki).

\section{The characterisation of lactobacillar proteolytic systems}

Our laboratory has sought to characterise the key components of and events in the proteolytic system of thermophilic industrial lactobacilli, with special emphasis on $L$. helveticus and $L$. delbrueckii subsp. bulgaricus. The $L$. helveticus we have used in our studies is an industrially utilised strain, 53/7, with highly favourable peptidolytic characteristics. During the past five years we have completed the molecular genetic characterisation of $\operatorname{six} L$. helveticus and two $L$. delbrueckii subsp. bulgaricus peptidases. We are currently engaged in cloning and sequencing a novel type of PrtP and a tripeptidase from $L$. helveticus (data not shown).

Characterisation of these components has allowed us to: i) initiate construction of modified lactococcal starter strains (an EU-BIOTECH II Starlab project); ii) analyse the regulation and interactions of the peptidase genes in L. helveticus (in collaboration with the Department of Food Science, University of Wisconsin-Madison), iii) test modified $L$. helveticus strains in a cheese process with an industrial partner; and iv) test the overproduction of individual peptidases.

Cloning the oligopeptide transport system from $L$. delbrueckii subsp. bulgaricus will allow us to compare the specificity and capacity of the transport systems of different LAB.

To control cell lysis, and thus to release peptidases, we have isolated and characterised a stress (e.g. $\mathrm{NaCl}$ ) induced promoter from $L$. helveticus (Smeds et al., unpublished). In the next sections I shall look at the results we have already published or submitted for publication.

\section{General aminopeptidases N, C and D of L. helveticus 53/7}

Aminopeptidases are capable of cleaving N-terminal amino acids from a wide variety of peptides differing in both size and composition. The general aminopeptidases we have characterised from L. helveticus 53/7 include PepN and PepC, which hydrolyse longer peptides, and a dipeptidase (PepD). 
Vol. 7 (1998): 267-282.

We (Varmanen et al. 1994) cloned the aminopeptidase $\mathrm{N}$ gene using nucleic acid hybridisation to detect the pepN gene from a $L$. helveticus 53/7 genomic library, with a fragment of the putative pepN gene from $L$. helveticus CNRZ32 (Nowakowski et al. 1993) as the probe. A $3.7 \mathrm{~kb}$ hybridisation positive insert directing aminopeptidase activity in $E$. coli was sequenced and found to contain only one open reading frame (ORF) of 2532 bp. This ORF had a coding capacity for a $95.8 \mathrm{kDa}$ protein that corresponded to the size of the lactococcal (Tan et al. 1992) and $L$. delbrueckii subsp. lactis PepNs (Klein et al. 1993). The deduced amino acid sequence was $49 \%$ homologous to Lactococcus lactis PepN, and showed $99 \%$ identity to the L. helveticus CNRZ32 pepN gene, sequenced later, (Christensen et al. 1995). Furthermore, the conserved catalytic and zinc-binding sites of the neutral zinc metallo-peptidase family were identified from the PepN sequence, confirming that the ORF cloned and sequenced did indeed encode the aminopeptidase $\mathrm{N}$ activity. The pepN mRNA analyses revealed $2.75 \mathrm{~kb}$ transcripts with two transcription start sites. These two sites verified the existence of two putative overlapping promoter regions in the DNA sequence. Our studies on pepN expression as a function of growth in a bioreactor showed that $p e p N$ transcripts remained at a high level during the stationary growth phase, too, in contrast to the steady-state levels of all other peptidase mRNAs we have analysed. Similarly, the level of total aminopeptidase activity remained constant throughout the stationary growth phase. The inhibition profiles of PepN showed that it is indeed a zinc-dependent metallopeptidase, being completely inhibited by ethylenediaminetetra-acetic acid (EDTA) whereas serine protease inhibitor phenylmethylsulphonylfluoride (PMSF) and a thiolblocking reagent, $p$-hydroxymercuribenzoate ( $p$ HMB), had only a slight effect on enzyme activity (Varmanen et al. 1994). Thus, the characteristics of $L$. helveticus PepN are in accordance with PepNs from other LAB (Kunji et al. 1996).

The second aminopeptidase we characterised was the PepC (Vesanto et al. 1994). The isola- tion procedure for the pepC gene was similar to that for $p e p N$. In a hybridisation positive clone showing aminopeptidase activity the pepC gene could be localised into a $3 \mathrm{~kb}$ fragment by deletion mapping. Sequencing of this fragment revealed two open reading frames (ORF1 and ORF2) of 1347 and $840 \mathrm{bp}$. ORF1 was preceded by a typical prokaryotic promoter region, and an inverted repeat structure with delta $G$ of -49.0 $\mathrm{kJmol}^{-1}$ was found downstream of the coding region. The deduced amino acid sequence of ORF1, with an encoding capacity of a $51.4 \mathrm{kDa}$ protein, shared $48.3 \%$ and $98 \%$ identity with the PepC proteins from Lactococcus lactis (ChapotChartier et al. 1993) and L. helveticus CNRZ32 (Fernández et al. 1994), thus confirming that ORF1 codes for an aminopeptidase C. mRNA size analyses revealed 1.7 and $2.7 \mathrm{~kb}$ transcripts. Further analysis with the pepC and ORF 2 specific probes showed that the downstream ORF2 was co-transcribed with the pepC gene at the exponential phase of growth whereas, at the stationary growth phase, $p e p C$ transcripts derived from the pepC promoter were below the detection limit and ORF2 was expressed by its own promoter (Vesanto et al. 1994). The 5' end mapping of the pepC transcripts revealed a transcription start different from that suggested for the pepC in the $L$. helveticus CNRZ32 pepC gene (Fernández et al. 1994). We also studied expression of pepC in L. helveticus as a function of growth in a bioreactor cultivation, and found that transcription of pepC was typical of the exponential growth phase expression. The level of total thiol- aminopeptidase activity, however, remained nearly constant throughout the stationary growth phase. Strain 53/7 PepC expressed in $E$. coli could be completely inhibited by $p \mathrm{HMB}$ and partially by PMSF whereas EDTA had only a minor effect. Thus, PepC is a thioldependent aminopeptidase belonging to the cysteine proteinase family. This allowed a rough estimation of the contributions of PepN and PepC to the total aminopeptidase activity in L. helveticus. Addition of EDTA or EDTA and $p$ HMB to $L$. helveticus cell lysates in the presence of Lys$p$-nitroanilide $(p \mathrm{NA})$ substrate reduced the ac- 


\section{AGRICULTURAL AND FOOD SCIENCE IN FINLAND}

\section{Seminar in honour of the 100th anniversary of MTT}

tivity to $10 \%$ and to below the detection limit, respectively, indicating that the aminopeptidase activity in $L$. helveticus is mainly due to the metalloaminopeptidase (Varmanen et al. 1994). Comparison of the level of pepN and pepC transcripts supports the conclusion that PepN is the main aminopeptidase in L. helveticus (data not shown). Our further studies on ORF2 have revealed that it codes for a transmembrane protein homologous to an unknown Bacillus protein that is expressed during sporulation (Vesanto and Palva, unpublished results).

We isolated $L$. helveticus $53 / 7$ dipeptidase gene (pepD) in the same way as pepN and pepC (Vesanto et al. 1996). An open reading frame (ORF) of 1422 bp was identified from a positive clone with a coding capacity of $53.5 \mathrm{kDa}$. The promoter and transcription terminator regions were also identified. The deduced amino acid sequence of the $53.5 \mathrm{kDa}$ protein shared no significant similarity with the sequences in the data bases but showed $99.8 \%$ overall similarity to PepDA from L. helveticus CNRZ32 (Dudley et al. 1996). For 5 'end mapping of prokaryotic transcripts we optimised a method based on the use of an automated DNA sequencer (Vesanto et al. 1996). The 5' end mapping of the $1.6 \mathrm{~kb}$ pepD transcript by the new and conventional primer extension methods gave consistent results. Expression studies showed that pepD was maximally expressed at late exponential growth. We also overexpressed the pepD gene in $E$. coli and purified PepD to homogeneity in three chromatographic steps. Studies of the PepD substrate specificity showed that PepD was able to hydrolyse a number of dipeptides with the exception of those containing proline residues. Optimal PepD activity was obtained at $\mathrm{pH} 6.0$ and $55^{\circ} \mathrm{C}$. Inhibition studies of PepD revealed that the enzyme could be inhibited by $p$ HMB and reactivated by dithiothreitol; EDTA, in contrast had no inhibitory effect (Vesanto et al. 1996). In addition to the lack of a homologous counterpart among $\mathrm{LAB}$, the enzymatic properties suggested that the two PepDs isolated from L. helveticus 53/7 and CNRZ32 represented a novel dipeptidase type.

\section{Proline specific peptidases of L. helveticus 53/7}

Milk proteins contain a large amount of proline residues, which, in free form impact a sweet flavour to cheese (Biede and Hammond 1979, Fox 1989). Proline-specific peptidases therefore play an important role in cheese ripening by degrading proline-containing peptides, which are sometimes bitter, and by making peptides accessible to further degradation by other peptidases through the removal of proline residues (Baankreis and Exterkate 1991).

We have performed the molecular genetic and biochemical characterisation of three different proline specific peptidases, i.e. X-prolyl dipeptidyl aminopeptidase (PepX) (Vesanto et al. 1995), prolinase (pepR) (Varmanen et al. 1996a) and iminopeptidase (PepI) (Varmanen et al. 1996b), from strain 53/7.

The X-prolyl dipeptidyl aminopeptidases cleave dipeptidyl residues from peptides by hydrolysing the peptide bond at the carboxyl side of the proline residue when this imino acid is the penultimate $\mathrm{N}$-terminal residue. The pepX gene cloned and sequenced from strain 53/7 was shown to be 2379 bp in size with a coding capacity for a $90.6 \mathrm{kDa}$ protein (Vesanto et al. 1995). The pepX gene was identified as a monocistronic transcription unit flanked by a typical prokaryotic promoter region and transcription terminator (delta $\mathrm{G}-84.1 \mathrm{~kJ} \mathrm{~mol}^{-1}$ ). The deduced amino acid sequence of the $90.6 \mathrm{kDa}$ protein shared $49.3,49.4$ and $77.7 \%$ overall similarity with the PepX proteins from Lactococcus lactis subsp. lactis (Mayo et al. 1991), Lactococcus lactis subsp. cremoris (Nardi et al. 1991) and $L$. delbrueckii subsp. lactis (Meyer-Barton et al. 1993), respectively. The size (2.6 kb) and 5'end of pepX mRNA were in agreement with the DNA sequence data. Similarly to the other $L$. helveticus peptidases analysed, expression of pepX was typical of exponential growth. The pepX gene was also overexpressed in pKK223-3 in E. coli followed by purification of PepX to homogeneity by ion-exchange and hydrophobic interaction 


\section{AGRICULTURAL AND FOOD SCIENCE IN FINLAND}

Vol. 7 (1998): 267-282.

chromatography. The enzyme was found to be a dimer $(165 \mathrm{kDa})$ with optimum activity at $\mathrm{pH}$ 6.5 and $45^{\circ} \mathrm{C}$. Furthermore, PepX was shown to be a metal-independent serine peptidase, having functional sulphhydryl groups at or near the active site (Vesanto et al. 1995). Thus, the characteristics of the L. helveticus PepX closely resembled those of other PepXs.

Prolinases cleave dipeptides with a proline residue at the $\mathrm{N}$-terminal amino acid. We cloned a prolinase $(p e p R)$ from strain 53/7 with a gene probe (Nowakowski et al. 1993) specific for a peptidase shown to have activity against di- and tripeptides (Varmanen et al. 1996a). The hybridisation positive clones obtained, however, did not show any enzyme activity against di- or tripeptides. Further analysis of one of the clones with a $5.5 \mathrm{~kb}$ insert revealed two ORFs, of 912 and 1602 bp, ORF2, located upstream of and opposite in orientation to ORF1, had a promoter region overlapping that of ORF1. ORF1 had a codine capacity for a $35 \mathrm{kDa}$ protein. This protein was shown to be capable of hydrolysing dipeptides when ORF1 was amplified by PCR with its control regions and expressed in E. coli. Among the dipeptides tested, the highest activity was obtained with a Pro-Leu substrate whereas among the tripeptides tested, only Leu-LeuLeu was marginally degraded. Thus, the $35 \mathrm{kDa}$ protein was identified as a prolinase (PepR) from the substrate-specificity profile and protein homologies (Varmanen et al. 1996a). The activity of the cloned PepR was inhibited by $p$ HMB. In accordance with the DNA sequence data, Northern and primer-extension analyses of pepR showed a $1.25 \mathrm{~kb}$ transcript and two adjacent transcription start sites, respectively. PepR protein was found to be $99.6 \%$ identical to the recently sequenced prolinase (PepPN) from $L$. helveticus CNRZ32 (Dudley and Steele 1994), thus further confirming the close similarity of the peptidases of these two L. helveticus strains, which otherwise differ from each other. Interestingly, analysis of the upstream ORF2 revealed that the deduced $59.5 \mathrm{kDa}$ protein encoded by this gene showed significant homology to several members of the family of $\mathrm{ABC}$ transporters.
Deletion constructs of ORF2 also clearly demonstrated that this upstream operon adversely affected PepR activity in E. coli, explaining the enzymatic inactivity of the original clones (Varmanen et al. 1996a).

Proline iminopeptidases (PepI) are able to liberate the $\mathrm{N}$-terminal proline residue from diand tripeptides. The L. helveticus $53 / 7$ proline iminopeptidase gene (pepI) cloned by us (Varmanen et al. 1996b), was found to be organised in an operon-like structure of three ORFs. ORF1 was preceded by a typical prokaryotic promoter region, and a putative transcription terminator identified as the pepI gene was present downstream of ORF3. Primer extension analyses on each ORF revealed only one transcription start site, upstream of ORF1, indicating an operon structure. The level of operon derived transcripts was so low that we could not determine the transcript size by Northern blot; nevertheless the RT-PCR clearly supported the operon structure of these three genes. The coding capacities of ORF1, ORF2 and ORF3 were for 50.7, 24.5 and $33.8 \mathrm{kDa}$ proteins, respectively. The ORF3-encoded PepI protein showed $65 \%$ identity to the PepI proteins from $L$. delbrueckii subsp. bulgaricus (Atlan et al. 1994) and L. delbrueckii subsp. lactis (Klein et al. 1994). The pepI gene was overexpressed in E. coli and purified to homogeneity in two chromatographic steps (Varmanen et al. 1996b). PepI was shown to be a dimer with optimum activity at $\mathrm{pH} 7.5$ and $40{ }^{\circ} \mathrm{C}$. Like the $L$. delbrueckii PepIs, the L. helveticus PepI was found to be a metal-independent serine peptidase with thiol group at or near the active site. Kinetic studies with PropNA as substrate revealed $\mathrm{K}_{\mathrm{m}}$ and $\mathrm{V}_{\max }$ values of $0.8 \mathrm{mM}$ and $350 \mathrm{mmol} \mathrm{min}^{-1}$ $\mathrm{mg}^{-1}$, respectively and a very high turnover number, $135000 \mathrm{~s}^{-1}$. The substrate specificities of the three PepIs identified differed from each other to some extent (Varmanen et al. 1996b), but we do not know whether these differences were due to assay conditions or they were true differences in the enzymatic properties of these PepIs.

The ORF1 and ORF2 encoded proteins were found to share homology with the members of 
the ABC (ATP binding casette) transporter family but to represent an unusual type (ORF1) among the bacterial ABC transporters (Varmanen et al. 1996b).

\section{Proline specific peptidases of L. delbrueckii subsp. bulgaricus}

Due to the importance of proline-specific peptidases we have also characterised two genes, pep $Q$ and orf Z, encoding a prolidase (PepQ) and a PepQ-like protein from $L$. delbrueckii subsp. bulgaricus (Rantanen and Palva 1997). The pepQ and orfZ genes showed $98 \%$ and $60 \%$ identity, respectively to the $L$. delbrueckii subsp. lactis pepQ; both pepQ and orf $\mathrm{Z}$ were preceded by a putative promoter region. The size of $p e p Q$ mRNA could be identified $(1.1 \mathrm{~kb})$ but, under the growth conditions used,we could only identify the expression of orfZ by RT-PCR. Both genes were shown to be monocistronic transcriptional units. The OrfZ protein, overexpressed in E. coli, revealed no enzymatic activity against the peptide substrates tested whereas the $L$. delbrueckii subsp. bulgaricus PepQ hydrolysed $\mathrm{X}$-Pro substrates similarly to other prolidases. Note that homologues of the $L$. delbrueckii subsp. bulgaricus orf $\mathrm{Z}$ and pep $Q$ genes appeared to be present in both $L$. delbrueckii subsp. lactis and L. helveticus (Rantanen and Palva 1997). The role of the cryptic orfZ gene and its putative gene product remains to be established.

\section{Oligopeptide transport system of L. delbrueckii subsp. bulgaricus}

As well as reforming peptidase analyses, we have started the characterisation of other components of the proteolytic systems of thermophilic lactobacilli. We have isolated the operon of the oligopeptide transport system from a lambda gt 10 based genomic library of $L$. delbrueckii subsp. bulgaricus (Peltoniemi et al. 1998 unpublished results). This operon is $6.1 \mathrm{~kb}$ in size and con- sists of five genes encoding the peptide binding protein (OppA), two integral membrane proteins (OppB and OppC) and two ATP-binding proteins (OppD and OppF). In L. delbrueckii subsp. bulgaricus, the opp genes in the operon are organized in much the same way as in Lactococcus lactis (Tynkkynen et al. 1993), i.e. oppDFBCA. Interestingly, an additional oppA-like gene is adjacent to the $o p p A$ of the operon. The identity of the oppDFBCA to that of L. lactis was shown to be $50 \%, 65 \%, 55 \%, 40 \%$ and $40 \%$, respectively (Peltoniemi et al. 1998, unpublished). The operon structure deduced from the DNA sequence of $o p p D F B C A$ has also been confirmed by mRNA analyses.

\section{Characterisation of surface layer protein and gene $(s / p A)$ from Lactobacillus brevis and use of slpA signals for heterologous protein production}

\section{General background of prokaryotic S-layer structures}

There are also many Lactobacillus-species among the over $300 \mathrm{~S}$-layer harbouring eu- and archaebacterial species (Messner and Sleytr 1992). The DNA sequence of the lactobacillar S-protein gene (slp) has been published for $L$. brevis, $L$. acidophilus and $L$. helveticus. The functions of the lactobacillar S-layers are mostly unknown, but apparently this structure is essential since all attempts to inactivate $s l p$ genes have failed (Boot 1996). The L. crispatus S-protein has been shown to mediate adhesion to type IV collagen (Toba et al. 1995).

For an average size cell, $5 \times 10^{5} \mathrm{~S}$-layer subunits have to be synthesised per cell generation in order to cover the entire cell surface with the 
Vol. 7 (1998): 267-282.

S-layer proteins (Messner and Sleytr 1992). The expression of a slp gene and the secretion machinery of an S-layer harbouring cell may thus be expected to be very efficient. These properties are obvious assets in the utilisation of S-proteins in biotechnological applications. We chose to study heterologous protein production in lactic acid bacteria, with the $L$. brevis slpA and to test the possibility of using SlpA as a carrier for foreign antigenic epitopes. L. brevis is a heterofermentative lactic acid bacterium commonly found in vegetable fermentations, sour dough, silage and the intestine of humans and animals (Wood 1992). Here, I shall look briefly at characterisation of the L brevis S-protein, gene, mRNA and in vivo expression and discuss the demonstration of heterologous protein secretion and intracellular production with of aid the $\operatorname{sip} A$ signals.

\section{Characteristics of the L. brevis S-protein and the sIpA gene}

We demonstrated the presence of the S-protein in intact L. brevis ATCC 8287 cells, boiled in Laemmli sample buffer, by SDS-PAGE analysis, which revealed only one major band, with an apparent molecular weight of $46 \mathrm{kDa}$ (Vidgrén et al. 1992). When the cells were treated with an antiserum raised against the isolated $46 \mathrm{kDa}$ protein and analysed by immuno-gold electron microscopy, post embedding immunoelectron microscopy clearly showed that the $46 \mathrm{kDa}$ protein was heavily concentrated in the outermost part of the cell wall of $L$. brevis cells (Vidgrén at al. 1992). The slpA gene was PCR cloned according to the $\mathrm{N}$-terminal sequence information of the intact $\mathrm{S}$-protein and internal tryptic peptides (Vidgrén et al. 1992).

The $L$. brevis slpA gene is 1395 bp in size with a coding capacity for a protein of 48159 daltons. The first 90 nucleotides of the structural gene encode a typical Gram-positive type signal peptide of 30 amino acid residues (Vidgrén et al. 1992). The $\operatorname{slpA}$ gene is preceded by a well conserved ribosome binding site (RBS) and two promoter regions, $\mathrm{P} 1$ and $\mathrm{P} 2$ with the -35 and -10 regions resembling the conserved prokaryotic -35 and -10 consensus sequences (von Heijne 1987). A strong transcription terminator sequence is present downstream of the two translation stop codons of $\operatorname{slpA}$.

At the time the basic characterisation of the L. brevis S-protein and $\operatorname{slpA}$ was published, data bases contained no genuinely related SlpA sequences (Vidgrén et al. 1992). The predicted amino acid sequences of the recently described L. acidophilus (Boot et al. 1993) and L. helveticus (EMBL Nucleotide Data Library: X91199 and X92752) slpA genes, however, show $35.7 \%$ (17) and $28.8 \%$ similarity to that of the L. brevis S-protein, respectively. Furthermore, L. brevis slpA probes hybridises to the chromosomal DNA of L. buchneri (Palva et al. 1992). Two slp genes with phase variation have been found in $L$. acidophilus, and one functional slp gene and a truncated slp 3'end in L. helveticus (Boot 1996). In L. brevis, in contrast only one $s l p$ gene is present (Palva et al. 1992).

\section{In vivo expression of the sIpA gene}

Determination of the size and 5'ends of the slpA transcripts revealed $1.5 \mathrm{~kb}$ mRNAs with two 5' ends located immediately downstream of the two -10 regions deduced from the DNA sequence, thus confirming that $\operatorname{slp} A$ is a monocistronic transcriptional unit and possesses two functional promoters (P1, P2) (Vidgrén et al. 1992). Determination of the stability of the slpA mRNA showed that the half- life of the slpA transcripts was 14 minutes (Kahala et al. 1997), indicating exceptional stability when compared with the typical half-lives of prokaryotic mRNAs. Recently, the half-lives of the L. acidophilus slpA and Aeromonas salmonicida vapA mRNAs have also been shown to be very stable (Boot et al. 1996, Chu et al. 1993). The long half-lives of these three S-layer mRNAs from three different species may indicate that a high stability of mRNA is a general feature of S-layer mRNAs. As slpA 


\section{Seminar in honour of the 100th anniversary of MTT}

mRNA mediates the synthesis of a major structural component of the cell, this high stability is not unexpected.

Study of the usage of the two L. brevis slpA promoters (P1, P2) at different stages of the growth revealed that the $\mathrm{P} 2$ promoter, which was located closer to the start codon, is efficiently used during both the logarithmic and early stationary phases, whereas $s l p A$ mRNA derived from P1 was only weakly detectable (Kahala et al. 1997). Further quantitative analyses showed that transcripts derived from both promoters are present throughout the entire growth phase and that the level of transcripts derived from promoter P2 is ten times higher than that derived from P1 (Kahala et al. 1997).

\section{S-layer synthesis}

In vivo expression studies of $L$. brevis showed that the kinetics of the accumulations of $\operatorname{sipA}$ mRNA and protein correlates well up to the onset of the stationary phase, when there is a sharp decrease in the level of slpA mRNA. The rate of mRNA decay was, however, slower than expected from the half-life of slpA transcripts, suggesting that residual transcription continues even though the total amount of S-protein does not further increase at the stationary phase (Kahala et al. 1997). The L. brevis S- layer protein is not released into the supernatant fractions at any of the growth phases studied, suggesting tight regulation of the S-layer synthesis and assembly (Vidgrén et al. 1992, Kahala et al. 1997). Breitwieser et al. (1992) demonstrated the presence of substantial amounts of S-layer subunits on the inner surface or within the peptidoglycan layer of Bacillus stearothermophilus, suggesting an intermediate phase between the synthesis and final location of the S-layer protein. This has also frequently been observed in S-layers of other gram-positive eubacteria (Breitwieser et al. 1992). However, in L. brevis over $95 \%$ of the S-layer subunits could be released with the SDSPAGE sample buffer from intact cells, as indicated by Western blot analyses of intact and dis- rupted cells (unpublished data). It appears, then, that basically no $L$. brevis $\mathrm{S}$-layer subunits accumulated inside the peptidoglycan layer before translocation to the outer surface.

\section{Heterologous protein secretion with the $s \mid p A$ signals}

To construct a secretion vector based on the slpA signals, we used a derivative (pKTH2095) of the shuttle vector pGK12 (Kok et al. 1984) as the carrier of the secretion cassette. The model secretion cassette contained the two promoters $(P 1, P 2)$, the signal sequence $(S S)$ and the transcription terminator $\left(t_{\text {slpA }}\right)$ of the L. brevis slpA and another terminator $(t)$ upstream of $s l p A$. The reporter gene was the B-lactamase (bla) of pUC19. The secretion vector (pKTH2121, see Fig. 2) was constructed stepwise by PCR (Savijoki et al. 1997).

To analyse the expression and secretion of Bla with the $s l p A$ cassette, we first transformed L. lactis (MG1614) with pKTH2121. The transformants kept the vector stabile and efficiently secreted B-lactamase into the culture medium. The utility of the cassette in other LAB was confirmed by transferring pKTH2121 into L. brevis (ATCC8287), L. plantarum (NCDO 1193), L. gasseri (NCK 334) and L. casei (ATCC 393) hosts and studying the expression and secretion of B-lactamase as a function of growth in flask cultivations. In each strain carrying pKTH2121, all detectable Bla activity was in the growth medium. The highest yield $(10240 \mathrm{U} / \mathrm{ml} ; 50 \mathrm{mg}$ $\mathrm{Bla} / \mathrm{l})$ in the culture supernatants was obtained with $L$. lactis at the early stationary phase. The highest production level of Bla in the early stationary phase L. brevis cells and in the exponential phase L. plantarum cells was $60 \%$ and $30 \%$, respectively, of that in L. lactis (Savijoki et al. 1997). The rate of Bla production was roughly equal in L. lactis and L. plantarum, whereas that of $L$. brevis was somewhat slower. In all strains studied,we observed degradation of B-lactamase due to proteolysis. With L. plantarum, L. gas- 
Vol. 7 (1998): 267-282.

A

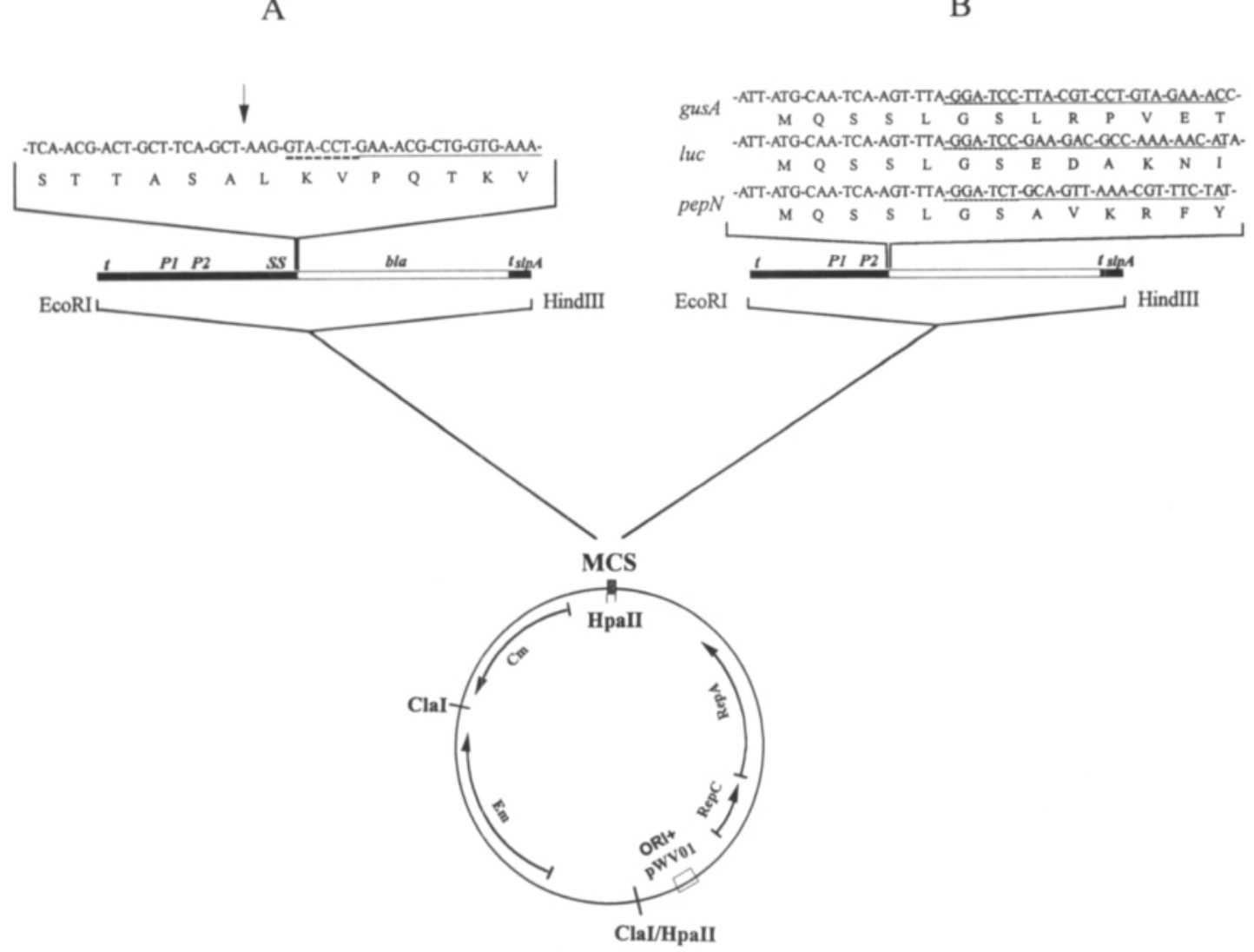

B

Fig. 2. Secretion and expression vectors based on the a slpA expression and secretion signals. A. The $L$ brevis promotersignal sequence $\left(P_{\text {slps }}-S S_{\text {stpe }}\right)$ region, the transcription terminators $\left(t\right.$ and $\left.t_{\text {stpes }}\right)$ and the $E$. coli B-lactamase (bla) gene were isolated by PCR amplifications and joined stepwise to form the final $t-P_{s l p A}-S S_{s p p A}-b l a-t_{s p s}$ cassette, which was then ligated with pKTH2095 to result in pKTH2121. The nucleotide and the corresponding amino acid sequences of the $P_{\text {slpA }}-S S_{\text {sppA }}-b l a$ joint region of the secretion construct are shown, and the signal peptide cleavage site is indicated by a vertical arrow. The reporter gene region is underlined. B. The expression cassette consisting of the $L$. brevis slpA promoter region and the reporter gene (gus, luc and $p e p N$ ) with the nucleotide and the corresponding amino acid sequences of the joint region. The genes, which were isolated using PCR, contained a sequence coding for the mature part of the polypeptide. The reporter gene region is underlined and the amino acid residues derived from the respective restriction enzyme recognition sites are marked with dotted lines.

seri and $L$. casei the Bla activity was already much lower at the early stationary phase, suggesting higher protease activity in these strains. Comparison of the activity and amount of Bla protein by Western blots revealed a good correlation and lack of cell associated B-lactamase. The size of Bla secreted to the culture medium was equal to that of the mature Bla of E. coli, suggesting that the enzyme was correctly proc- essed. The $L$. brevis slpA promoters were very efficiently recognized in L. lactis, L. brevis and L. plantarum, whereas in L. gasseri, the slpA promoter region appeared to be recognised at a lower level and in L. casei the level of transcripts was below the detection limit (Savijoki et al. 1997). Furthermore, high integrity and the correct size of bla mRNA were demonstrated in all these species except $L$. casei. 


\section{AGRICULTURAL AND FOOD SCIENCE IN FINLAND}

Seminar in honour of the 100th anniversary of MTT

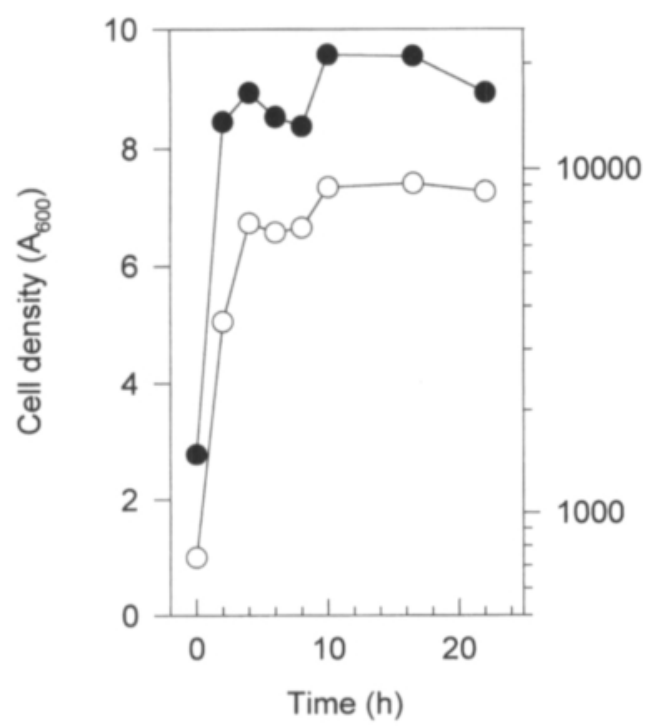

Fig. 3. Secretion of B-lactamase under $\mathrm{pH}$ control in L. lactis MG1614 carrying the pKTK2121 secretion vector. Closed and open circles show the Bla activities and cell densities as a function of time. Cells were grown in double strength M17 media containing $2 \%$ glucose ( $2 \times$ M17G) and in MRS broth. Propagation was at $30^{\circ} \mathrm{C}$ in a bioreactor (Biostat ${ }^{\circ} \mathrm{B}$, Medical Brown) with gentle (100 rpm) stirring and without aeration. Glucose was added in amounts required to maintain the final concentration of $2 \%$, and the $\mathrm{pH}$ of the culture was adjusted to 5.5 by $1 \mathrm{~N} \mathrm{NH}_{3}$ Samples were taken at different times up to $22 \mathrm{~h}$, and the supernatant fractions were analysed.

To improve the stability and production of B-lactamase, we grew L. lactis in a bioreactor at constant $\mathrm{pH}$ and glucose feeding (Fig. 3). Under such conditions the yield of Bla could be increased up to $80 \mathrm{mg} / 1$ (Savijoki et al. 1997). After maximum activity was reached (10 after the cell density $A_{600}=1$ ) the level of B-lactamase was kept stabile at the stationary phase of growth, indicating stabilisation of Bla activity with the $\mathrm{pH}$ control and glucose. Comparison of yields of B-lactamase production in lactococci revealed that a hybrid expression-secretion unit consisting of a strong cytoplasmic lactococcal promoter and an indigenous lactococcal signal sequence (Koivula et al. 1991, Sibakov et al. 1991) resulted in only $14 \%$ of the Bla activity obtained with the slpA-based secretion system. This finding supports the high efficiency of the $s$ lpA expression and secretion signals. The kinetics of Blactamase accumulation shows that the Bla-production is basically restricted to the exponential phase of growth. Sixty-five per cent of the maximum Bla activity was reached within $2 \mathrm{~h}$ of the cell density $A_{600}=1$ (Fig. 3), implying a very high rate of secretion with a calculated value of $5 \mathrm{x}$ $10^{5} \mathrm{molecules} / \mathrm{cell} / \mathrm{h}$. This value is comparable to or exceeds the best exoenzyme-producing laboratory strains of Bacillus (Simonen and Palva 1993), and thus suggests utility of lactococci as production hosts. However, lengthening the effective duration of the production phase to raise product yields requires either optimization of growth or use of immobilized cell systems.

\section{Intracellular protein production with the slpA signals}

To analyse the utility of the slpA promoters for intracellular protein production, we constructed three reporter gene cassettes, B-glucuronidase (gusA), luciferase (luc) and aminopeptidase $\mathrm{N}$ $(p e p N)$, in the pKTH2095 based vector under the slpA P1 and P2 promoters (Fig. 2b) (Kahala and Palva 1998). The expression of reporters was studied in three different lactic acid bacteria hosts, L. lactis, L. plantarum and L. gasseri, as a function of growth. The slpA promoters were identified in each strain but significant variations in GusA, Luc and PepN activities at both transcriptional and product yield levels were evident in the different strains. The highest levels of GusA and Luc activities were obtained in L. lactis, which produced, for example, GusA up to $15 \%$ of total cellular proteins. The highest level of PepN activity, $28 \%$ of total cellular proteins, was achieved in L. plantarum (Kahala and Palva 1998). The $s l p A$ promoters thus have significant potential for future use in protein production in different LAB. The utility of the slpA signals, is, however, strain and production gene dependent and must be tested separately for each gene and host of interest. 


\section{AGRICULTURAL AND FOOD SCIENCE IN FINLAND}

Vol. 7 (1998): 267-282.

In the light of present knowledge, we can expect that lactobacillar S-layers will be further developed for different biotechnological applications. One obvions application of the L. brevis $\mathrm{S}$-protein currently being studied is as a carrier vehicle of foreign antigenic epitopes. Further elucidation of the adhesive properties of the $L$. brevis $\mathrm{S}$-protein may also allow and extend its utilisation as a carrier of oral vaccines and other substances for animal and human use. Further developments will include the extension of the use of the $L$. brevis slpA signal for both secretion and intracellular protein production to improve fermentation processes.

Acknowledgements. The author is grateful to M.Sc. Kirsi Savijoki and M.Sc. Minna Kahala for drawing the figures.

\section{References}

Ardö, Y. \& Larsson, P. 1989. Studies of peptidolysis during early maturation and its influence on low-fat cheese quality. Milchwissenschaft 44: 485-490.

Atlan, D., Gilbert, C., Blanc, B. \& Portalier, R. 1994. Cloning, sequencing and characterization of the pepIP gene encoding a proline iminopeptidase from Lactobacillus delbrueckii subsp. bulgaricus CNRZ 397. Microbiology 140: 527-535.

Baankreis, R. \& Exterkate, F. 1991. Characterization of a peptidase from Lactococcus lactis ssp. cremoris HP that hydrolyses di- and tripeptides containing proline or hydrophobic residues as the aminoterminal amino acid. Systematic and Applied Microbiology 14: 317-323.

Bartels, H., Johnson, M. \& Olson, N. 1987a. Accelerated ripening of Gouda cheese. 1. Effect of heat-shocked thermophilic lactobacilli and streptococci on proteolysis and flavor development. Milchwissenschaft 42: 83-88.

-, Johnson, M. \& Olson, N. 1987b. Accelerated ripening of Gouda cheese. 2. Effect of freeze-shocked Lactobacillus helveticus on proteolysis and flavor development. Milchwissenschaft 42: 139-144.

Biede, S.L. \& Hammond, E.G. 1979. Swiss cheese flavor. 1. Chemical analysis. Journal of Dairy Science 62: 227-237.

Boot, H.J. 1996. The surface layer protein genes of Lactobacillus acidophilus. Academic thesis. Faculties of Biology and Chemistry of University of Amsterdam. The Netherlands.

- , Kolen, C.P.A.M., Andreadaki, F.J., Leer, R.J. \& Pouwels P.H. 1996. The Lactobacillus acidophilus S-protein gene expression site comprises two consensus promoter sequences one of which directs transcription of stable mRNA. Journal of Bacteriology 78: 5388-5394.

- , Kolen, C.P.A.M., van Noort, J.M. \& Pouwels, P.H. 1993. S-layer protein of Lactobacillus acidophilus ATCC 4356: Purification, expression in Escherichia coli, and nucleotide sequence of the corresponding gene. Journal of Bacteriology 175: 6089-6096.

Breitwieser, A., Gruber, K. \& Sleytr, U.B. 1992. Evidence for an S-layer protein pool in the peptidoglycan of Bacillus stearothermophilus. Journal of Bacteriology 174: 8008-8015.

Chapot-Chartier, M.-P., Nardi, M., Chopin, M.-C., Chopin, A. \& Gripon, J.-C. 1993. Cloning and sequencing of $p e p C$, a cysteine aminopeptidase gene from Lactococcus lactis subsp. cremoris AM2. Applied and Environmental Microbiology 59: 330-333.

Chopin, A. 1993. Organization and regulation of genes for amino acid biosynthesis in lactic acid bacteria. FEMS Microbiology Reviews 12: 21-38.

Christensen, J., Lin, D., Palva, A. \& Steele, J. 1995. Sequence analysis, distribution and expression of an aminopeptidase from Lactobacillus helveticus CNRZ32. Gene 155: 89-93.

Chu, S., Gustafson, C.E., Feutrier, J., Cavaignac, S. \& Trust, T.J. 1993. Transcriptional analysis of the Aeromonas salmonicida S-layer protein gene vapA. Journal of Bacteriology 175: 7968-7975.

De Vos, W.M., Huis in't Veld, J.H.J. \& Poolman, B. (eds), 1993. Lactic acid bacteria: genetics, Metabolism and Applications. FEMS Microbiology Reviews 12: 1-272.

De Vuyst, L. \& Vandamme, E.J. 1994. Lactic acid bacteria and Bacteriocins: their practical importance. In: de Vuyst, L. \& Vandamme, E.J. (eds.). Bacteriocins of lactic acid bacteria. London: Blackie Academic \& Professional. p. 1-11.

Dudley, E., Husgen, A., Hr, W. \& Steele, J. 1996. Sequencing, distribution and inactivation of the dipeptidase A gene (pepDA) from Lactobacillus helveticus CNRZ32. Journal of Bacteriology 178: 710-714.

- \& Steele, J. 1994. Nucleotide sequence and distribution of the pepPN gene from Lactobacillus helveticus CNRZ32. FEMS Microbiology Letters 119: 4146.

El Soda, M. 1993. The role of lactic acid bacteria in accelerated cheese ripening. FEMS Microbiology $R e-$ views 12: 239-252.

Fernández, L., Bhowmik, T. \& Steele, J. 1994. Characterization of the Lactobacillus helveticus CNRZ32 pepC gene. Applied and Environmental Microbiology 60: 333-336. 


\section{AGRICULTURAL AND FOOD SCIENCE IN FINLAND}

\section{Seminar in honour of the 100th anniversary of MTT}

Fox, P. 1989. Proteolysis during cheese manufacture and ripening. Journal of Dairy Science. 72: 1379-1400.

Gasson, M.J. \& de Vos, W.M. (eds.). 1994. Genetics and biotechnology of lactic acid bacteria. 1. ed. London: Blackie Academic \& Professional. 300 p.

Holzapfel, W.H., Geisen, R. \& Schillinger, U. 1995. Biological preservation of foods with reference to protective cultures, bacteriocins and food-grade enzymes. International Journal of Food Microbiology 24: 343-362.

Jensen, R.G. (ed.). 1995. Handbook of milk composition. San Diego: Academic Press. 919 p.

Kahala, M. \& Palva, A. 1998. The expression signals of the Lactobacillus brevis slpA gene directs efficient heterologous protein production in lactic acid bacteria. Applied Microbiology and Biotechnology (in press).

- Savijoki, K. \& Palva, A. 1997. In vivo expression of the Lactobacillus brevis S-layer gene. Journal of Bacteriology 179: 284-286.

Kailasapathy, K. \& Rybka, S. 1997. L. acidophilus and Bifidobacterium spp. - their therapeutic potential and survival in yogurt. Australian Journal of Dairy Technology 52: 28-35.

Klaenhammer, T.R. 1995. Genetics of intestinal lactobacilli. International Dairy Journal 5: 1019-1058.

Klein, J., Klein, U., Schad, M. \& Plapp, R. 1993. Cloning, DNA sequence and partial characterization of $p e p N$, a lysyl aminopeptidase from Lactobacillus delbrueckii ssp. lactis DSM7290. European Journal of Biochemistry 217: 105-114.

- , Schmidt, U. \& Plapp, R. 1994. Cloning, heterologous expression, and sequencing of a novel proline iminopeptidase gene, pepl, from Lactobacillus delbrueckii susbsp. lactis DSM7290. Microbiology 140: 1133-1139.

Koivula, T., Sibakov, M. \& Palva, I. 1991. Isolation and characterization of Lactococcus lactis subsp. lactis promoters. Applied and Environmental Microbiology 57: 333-340.

Kok, J., van der Vossen, M. B. M. \& Venema, G. 1984. Construction of plasmid cloning vectors for lactic streptococci which also replicate in Bacillus subtilis and Escherichia coli. Applied and Environmental Microbiology 48: 726-731.

Kunji, E.R.S., Mierau, I., Hagting, A., Poolman, B. \& Konings, W.N. 1996. The proteolytic systems of lactic acid bacteria. Antonie van Leeuwenhoek 70: 187-221.

Lindegren, S.E. \& Dobrogosz, W.J. 1990. Antagonistic activities of lactic acid bacteria in food and feed fermentations. FEMS Microbiology Reviews 87: 149163.

Mayo, B., Kok, J., Venema, K., Boeckelmann, W., Teuber, M., Reinke, H. \& Venema, G. 1991. Molecular cloning and sequence analysis of the X-prolyl dipeptidyl aminopeptidase gene from Lactococcus lactis subsp. cremoris. Applied and Environmental Microbiology 57: 38-44.

Messner, P. \& Sleytr, U.B. 1992. Crystalline bacterial cell surface layers. In: Rose, A.H. (ed.). Advances in Microbial Physiology. London: Academic Press. p. 213275.

Meyer-Barton, E.C., Klein, J.R., Imam, M. \& Plapp, R. 1993. Cloning and sequence analysis of the X-pro- |yl- dipeptidyl aminopeptidase gene (pepX) from Lactobacillus delbrueckii subsp. lactis DSM7290. Applied and Environmental Microbiology 40: 82-89.

Nardi, M., Chopin, M.-C., Chopin, A., Cals, M.-M. \& Gripon, J.-C. 1991. Cloning and DNA sequence of an X-prolyl dipeptidyl aminopeptidase gene from Lactococcus lactis subsp. lactis NCDO 763. Applied and Environmental Microbiology 57: 45-50.

Nowakowski, C.M., Bhowmik, T.K. \& Steele, J.L. 1993. Cloning of peptidase genes from Lactobacillus helveticus CNRZ32. Applied Microbiology and Biotechnology 39: 204-210.

Olson, N.F. 1990. The impact of lactic acid bacteria on cheese flavour. FEMS Microbiology Reviews 87: 131-148.

Palva, A., Vidgrén, G., Palva, I., Pakkanen, R. \& Lounatmaa, K. 1992. Characterization of expression and secretion signals from Lactobacillus brevis for use in food and feed industry. Proceedings of Sixth Forum for Applied Biotechnology. Med. Fac. Landbouww. Univ. Gent, 57/4b. p. 1891-1898.

Pot, B., Ludwig, W., Kersters, K. \& Schleifer, K.-H. 1994. Taxonomy of lactic acid bacteria. In: de Vuyst, L. \& Vandamme, E.J. (eds.). Bacteriocins of lactic acid bacteria. London: Blackie Academic \& Professional. p. 13-90.

Rantanen, T. \& Palva, A. 1997. Lactobacilli carry cryptic genes encoding peptidase-related proteins: characterization of a prolidase gene $(p e p Q)$ and a related cryptic gene (orfZ) from Lactobacillus delbrueckii subsp. bulgaricus. Microbiology 143: 3899-3905.

Salminen, S., Isolauri, E. \& Salminen, E. 1996. Clinical uses of probiotics for stabilizing the gut mucosal barrier: successful strains and future challenges. Antonie van Leeuwenhoek 70: 347-358.

Savijoki, K., Kahala, M. \& Palva, A. 1997. High level heterologous protein production in Lactococcus and Lactobacillus using a new secretion system based on the Lactobacillus brevis S-layer signals. Gene 186: 255-262.

Schleifer, K.H. \& Ludwig, W. 1995. Phylogenetic relationship of lactic acid bacteria. In: Wood, B.J.B. \& Holzapfel, W.H. (eds.) The genera of lactic acid bacteria. London: Blackie Academic \& Professional. p. $7-$ 18.

Sibakov, M., Koivula, T., von Wright, A. \& Palva, I. 1991. Secretion of TEM B-lactamase with signal sequences isolated from the chromosome of Lactococcus lactis subsp. lactis. Applied and Environmental Microbiology 57: 341-348.

Simonen, M. \& Palva, I. 1993. Protein secretion in Bacillus species. Microbiology Reviews 57: 109-137.

Tan, P., van Alen-Boerrigter, I., Poolman, B, Siezen, R., de Vos, W. \& Konings, W. 1992. Characterization of the Lactococcus lactis pepN encoding an aminopeptidase homologous to mammalian aminopeptidase $\mathrm{N}$. FEBS Letters 306: 9-16.

Tannock, G.W. 1995. Microecology of the gastrointestinal tract in relation to lactic acid bacteria. International Dairy Journal 5: 1059-1070.

Toba, T., Virkola, R., Westerlund, B., Björkman, Y., Sillanpää, J., Vartio, T., Kalkkinen, N. \& Korhonen, T. 1995. A collagen-binding S-layer protein in Lacto- 
Vol. 7 (1998): 267-282.

bacillus crispatus. Applied and Environmental Microbiology 61: 2467-2471.

Tynkkynen, S., Buist, G., Kunji, E., Kok, J., Poolman, B., Venema, G. \& Haandrikman, A.J. 1993. Genetic and biochemical characterization of the oligopeptide transport system of Lactococcus lactis. Journal of Bacteriology 175: 7523-7532.

Varmanen, P., Rantanen, R. \& Palva, A. 1996b. An operon from Lactobacillus helveticus composed of a proline iminopeptidase gene (pep/) and two genes coding for putative members of the $A B C$ transporter family of proteins. Microbiolgy 142: 3459-3468.

-, Steele, J. \& Palva, A. 1996a. Characterization of a prolinase gene and its product and an adjacent ABC transporter from Lactobacillus helveticus. Microbiology 142: 809-816.

-, Vesanto, E., Steele, J. \& Palva, A. 1994. Characterization and expression of the pep $\mathrm{N}$ gene encoding a general aminopeptidase from Lactobacillus helveticus. FEMS Microbiology Letters 124: 315-320.

Venema, G., Huis in't Veld, J.H.J. \& Hugenholtz, J. (eds.). 1996. Lactic acid bacteria: Genetics, Metabolism and Applications. Proceedings of the Fifth Symposium on Lactic Acid Bacteria. Veldhoven, The Netherlands, 8-12 September 1996. Antonie van Leeuwenhoek 70. 358 p. Dordrecht: Kluwer Academic Publishers.

Vesanto, E., Peltoniemi, K., Purtsi, T., Steele, J. L. \& Palva, A. 1996. Molecular characterization, overexpres- sion and purification of a novel dipeptidase from Lactobacillus helveticus. Applied Microbiology and Biotechnology 45: 638-645.

-, Savijoki, K., Rantanen, T., Steele, J.L. \& Palva, A. 1995. An X-prolyl dipeptidyl aminopeptidase (pepX) gene from Lactobacillus helveticus. Microbiology 141: 3067-3075.

- , Varmanen, P., Steele, J.L. \& Palva, A. 1994. Characterization and expression of the Lactobacillus helveticus pepC gene encoding a general aminopeptidase. European Journal of Biochemistry 224: 991-997.

Vidgrén, G., Palva, I., Pakkanen, R., Lounatmaa, K. \& Palva, A. 1992. S-layer protein gene of Lactobacillus brevis: Cloning by polymerase chain reaction and determination of the nucleotide sequence. Journal of Bacteriology 174: 7419-7427.

Von Heijne, G. 1987. Sequence Analysis in Molecular Biology. London: Academic Press. 188 p.

Wells, J.M., Robinson, L.M., Chamberlain, L.M., Schonfield, K.M. \& Le Page, R.W.F. 1996 Lactic acid bacteria as vaccine delivery vehicles. Antonie van Leeuwenhoek 70: 317-330.

Wood, B.J. (ed.). 1992. The lactic acid bacteria in health and disease. Volume 1. London: Elsevier Applied Science. $485 \mathrm{p}$.

Wood, B.J.B. \& Holzapfel, W.H. (eds.). 1995. The genera of lactic acid bacteria. Volume 2. London: Blackie Academic \& Professional. 398 p. 


\title{
SELOSTUS
}

\section{Terveysvaikutteisten elintarvikkeiden tuottamista edesauttavat maitohappobakteerien molekyyligeneettiset tutkimukset}

\author{
Airi Palva \\ Maatalouden tutkimuskeskus
}

Maitohappobakteereita (MHB) käytetään laajamittaisesti erilaisten hapatettujen maito-, liha-, vihannesja leipomotuotteiden valmistuksessa elintarviketeollisuudessa, panimo- ja viiniteollisuudessa sekä säilörehun valmistuksessa. Eräät MHB-kannat ovat nousemassa yhä tärkeämpään asemaan myös terveysvaikutteisina probiootteina. MHB:n molekyyligeneettisen tutkimuksen avulla pyritään luonnehtimaan keskeisistä hapatekannoista niiden fermentaatioprosessin ja siten lopputuotteen onnistumisen kannalta oleellisten ominaisuuksien geenitaustaa. Näin saatava tieto mahdollistaa mm. MHB:n oleellisten prosessiominaisuuksien stabiloinnin ja parantamisen ge- neettisen muokkauksen avulla. Tämän katsauksen tarkoituksena on esitellä kirjoittajan oman, MHB:n molekyyligenetiikkaan keskittyvän tutkimusryhmän kahden keskeisen projektin tavoitteita, tuloksia ja soveltamismahdollisuuksia mm. terveysvaikutteisten elintarvikkeiden tuottamisessa. Käsiteltävät alueet ovat termofiilisten Lactobacillus-sukuun kuuluvien teollisten hapatekantojen proteolyyttisen järjestelmän molekyyligeneettinen ja biokemiallinen karakterisointi sekä Lactobacillus- pintaproteiinitutkimus, jonka avulla kehitetään elintarvike-, rehu-, rokote- ja diagnostiikkakäyttöön soveltuvia proteiinituottojärjestelmiä. 